\title{
Diagnosis dan Tata Laksana Sifilis Kongenital
}

\author{
Mutiara Siagian, Rinawati
}

Seorang bayi perempuan yang menderita sebagai sifilis kongenital dilahirkan oleh ibu dengan diagnosis sifilis stadium II yang tidak mendapat pengobatan. Pada umumnya didapatkan hepatosplenomegali, ikterus, kelainan kulit, pseudoparalisis, anemia, trombositopenia maupun monositosis, pada pemeriksaan fisik maupun laboratorium namun, manifestasi klinis tersebut tidak ditemukan pada kasus ini. Hal ini sesuai dengan kepustakaan yang menyatakan bahwa $50 \%$ bayi dengan sifilis kongenital asimtomatik. Pemeriksaan mikroskopik lapangan pandang gelap tidak dilakukan karena tidak didapatkan bahan pada bayi berupa sekret hidung maupun serum dari lesi kulit. Pemeriksaan radiologi didapatkan gambaran radio luser di metafisis tulang femur kanan dan kiri disertai penebalan korteks, penebalan korteks juga tampak di humerus kanan; kelainan ini sesuai dengan sifilis kongenital. Pasien ini diobati dengan penisilin prokain $75000 \mathrm{U} / \mathrm{kali}$ intra muskular satu kali sehari selama sepuluh hari. Pemantauan secara klinis dan pemeriksaan serologis perlu dilakukan secara berkala. Pada usia 51 hari, tidak didapatkan kelainan. Keadaan umum baik, didapatkan kenaikan berat badan 27 gram/ hari, dan penambahan tinggi badan 8 sentimeter dalam 51 hari. Pemantauan selanjutnya yang diperlukan adalah pemeriksaan klinis setiap bulan sampai bulan ke-3, kemudian bulan ke- 6 dan ke-12 sesudah pengobatan dan pemantauan serologi VDRL direncanakan pada bulan ke-3 dan ke-6 untuk menilai keberhasilan terapi yang diberikan. Dengan terapi yang adekuat diharapkan komplikasi sifilis kongenital dini dan lanjut tidak terjadi.

Kata kunci: sifilis kongenital, kandiloma akuminatum VDRL, TPHA

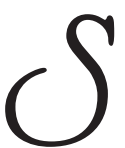

ifilis pertama kali ditemukan di Eropa pada akhir abad ke-15 $15^{1}$ dan pada tahun 1905 , Schaundinn dan Hoffman menemukan penyebab penyakit ini yaitu Treponema pallidum. ${ }^{2}$ Penyakit sifilis didapat ditularkan (acquired) melalui kontak seksual. Sifilis primer ditandai dengan adanya luka yang tidak nyeri, mengeras, dan sembuh dalam 7-10 hari. Sifilis sekunder ditandai dengan kelainan pada kulit dan membran mukosa yang terjadi selama 4-6 minggu. Jika berlangsung lama, lesi pada sifilis tertier dapat

Dr. Mutiara Siagian: PPDS Ilmu Kesehatan Anak FKUI, Jakarta

Alamat korespondensi:

Dr. Rinawati, Sp.A.

Staf Subbagian Perinatologi. Bagian Ilmu Kesehatan Anak FKUI-RSCM. Jl. Salemba no. 6. Jakarta 10430 .

Telepon dan Fax.: 021- 3154020. mengenai mata, kulit, tulang, visera, susunan saraf pusat, dan sistem kardiovaskular. ${ }^{3}$ Sifilis kongenital terjadi pada bayi yang ditularkan ibunya yang menderita sifilis. Bila tidak diobati dengan baik, infeksi dapat mengenai berbagai organ janin dan dapat mengakibatkan kematian. ${ }^{4}$ Sifilis kongenital merupakan penyakit yang jarang dilaporkan. Di Amerika Serikat tahun 1997, didapatkan 3,2 kasus baru per 100.000 populasi. ${ }^{2}$ Di RSUPN Cipto Mangunkusumo, sejak tahun 1995 tidak didapatkan laporan mengenai kasus ini. Tujuan laporan kasus ini adalah untuk mengingatkan kembali upaya diagnostik dan tata laksana pasien dengan sifilis kongenital.

\section{Kasus}

Seorang bayi perempuan, lahir di kamar bersalin Bagian Kebidanan dan Kandungan RSCM dari ibu 
yang menderita sifilis stadium II dan kondiloma akuminatum, serta ayah yang menderita sebagai sifilis laten. Pasien lahir cukup bulan melalui operasi sito bedah kaisar atas indikasi fungsi dinamik jantung plasenta $($ FDJP $)=4$, dengan berat lahir 1800 gram dan panjang lahir 40 sentimeter. Nilai Apgar 9 pada menit pertama dan 10 pada menit ke- 5 .

Dari anamnesis dengan ibu pasien didapatkan keterangan bahwa ibu pasien didiagnosis di Bagian Kulit dan Kelamin RSCM sebagai sifilis stadium II berdasarkan keterangan suami yang berperilaku seksual risiko tinggi, serta ditemukannya lesi pada kedua telapak tangan dan kaki berupa bercak eritematosa, sebagian berbentuk plak berukuran lentikular sampai numular dengan skuama kolaret, dan pembesaran kelenjar getah bening submandibula kiri dan inguinal medial kiri. Pada pemeriksaan serologi didapatkan titer Venereal Disease Research Laboratory (VDRL) (+) 1:16 dan Treponema pallidum Hemagglutination Assay (TPHA) (+) 1:320. Selain itu di daerah vulva tampak vegetasi multipel dengan permukaan verukosa berwarna putih kemerahan berkelompok, lunak kenyal pada labia mayora dan perineum yang didiagnosis baik secara klinis maupun histopatologis sebagai kondiloma akuminatum. Ayah pasien menderita sebagai sifilis laten berdasarkan keterangan bahwa sejak dua tahun yang lalu pernah menderita luka di penis yang tidak nyeri dan sembuh sendiri, berperilaku seksual risiko tinggi dan didukung oleh titer VDRL (+) 1:16 dan TPHA (+) 1:640.

Pasien adalah anak pertama, ibu pasien belum mendapat pengobatan yang adekuat dan ayah pasien direncanakan diberi pengobatan benzatin penisilin 2,4 juta unit intra muskular selang seminggu selama tiga kali berturut-turut.

Pada pemeriksaan fisis saat lahir didapatkan pasien tampak sadar, menangis kuat, tidak sesak, tidak sianosis. Tanda vital dalam batas normal. Berat lahir 1800 gram dan panjang lahir 41 sentimeter. Kepala bulat, ubun-ubun besar datar, lingkar kepala 29 sentimeter. Konjungtiva tidak pucat, sklera tidak ikterik, dan tidak didapatkan adanya sekret. Kelenjar getah bening tidak membesar. Dada terlihat simetris, tidak terdapat retraksi. Bunyi jantung I-II normal, tidak terdengar bising maupun irama derap. Suara nafas vesikular, tidak terdengar ronki. Perut teraba lemas, hati dan limpa tidak teraba, bising usus normal. Pada genitalia tidak didapatkan kelainan. Alat gerak akral hangat, perfusi perifer baik. Setelah keadaan pasien stabil, dilakukan pemeriksaan dengan metode Ballard, dengan hasil bayi sesuai dengan usia gestasi 39 minggu. Pada saat itu ditegakkan diagnosis kerja neonatus cukup bulan-kecil masa kehamilan (NCB-KMK), sifilis kongenital.

Pada pemeriksaan darah tepi didapatkan kadar $\mathrm{Hb} 13,3$ g/dl, Ht 40 volume \%, leukosit $6.800 / \mathrm{ml}$ dan trombosit $249000 / \mathrm{ml}$. Hitung jenis (\%): basofil 0 , eosinofil 4, batang 2, segmen 41, limfosit 50, monosit 3. Hasil pemeriksaan C-Reactive Protein (CRP) (-), IT ratio 0,07, SGOT 54 U/l, SGPT 16 U/l. Hasil pemeriksaan cairan serebro spinal (CSS) tampak jernih, Nonne (-), Pandy (-), sel 36/3, NaCl $714 \mathrm{mg} / \mathrm{dl}, \mathrm{Cl} 433 \mathrm{mg} / \mathrm{dl}$, glukosa $40 \mathrm{mg} / \mathrm{dl}$, protein $96 \mathrm{mg} / \mathrm{dl}$. VDRL dan TPHA dari bahan CSS negatif, VDRL serum (+) 1:4, TPHA serum (+) 1:320. Kultur darah steril. Pemeriksaan radiologi (baby gram) memperlihatkan gambaran radio lusen di metafisis tulang femur kanan dan kiri disertai penebalan korteks, serta penebalan korteks di humerus kanan. Pada tulang kepala, iga, tulang belakang, dan pelvis tidak tampak kelainan. Keterangan di atas sesuai dengan gambaran tulang pada sifilis kongenital. (Gambar 1)

Pasien dirawat dalam inkubator, diberikan cairan intravena dekstrosa $10 \% 4,5 \mathrm{ml} / \mathrm{jam}$, vitamin $\mathrm{K} 1 \mathrm{mg}$ intra muskular, dan penisilin Prokain 75000 unit per hari intramuskular selama 10 hari berturut-turut. Direncanakan pemantauan secara klinis setiap bulan sampai bulan ke-3, selanjutnya bulan ke-6 dan ke-12 sesudah pengobatan. Pemantauan serologi VDRL pada bulan ke-3 dan ke-6.

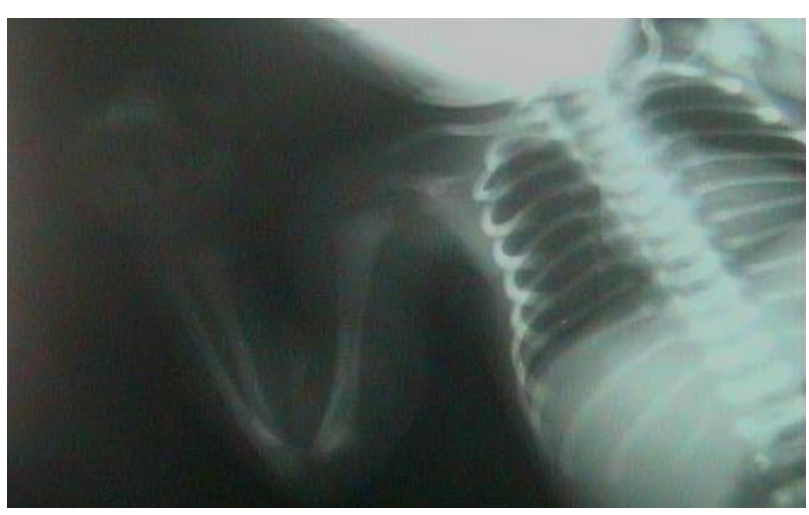

Gambar 1. Gambaran radio lusen pada metafisis tulang disertai penebalan korteks di tulang humerus kanan 


\section{Kepustakaan}

\section{Definisi}

Sifilis kongenital adalah penyakit sifilis yang diderita bayi dengan manifestasi klinis sifilis kongenital; atau ditemukannya Treponema pallidum pada lesi, plasenta, tali pusat atau otopsi jaringan; atau bayi yang dilahirkan oleh ibu penderita sifilis yang belum mendapat pengobatan atau telah mendapat pengobatan namun tidak adekuat sebelum atau selama kehamilan, atau ibu yang telah mendapat terapi penisilin tetapi tidak menunjukkan respons serologi; atau ditemukannya salah satu dari hal berikut, yaitu pemeriksaan radiologi tulang panjang dan/atau cairan serebrospinal yang sesuai gambaran sifilis kongenital. 4,5

\section{Epidemiologi}

Sejak tahun 1980, di Amerika Serikat terdapat peningkatan yang pesat jumlah kasus sifilis primer dan sekunder dan mencapai puncaknya pada tahun 1990 yaitu 20,3 kasus per 100000 populasi. Namun kemudian terjadi penurunan jumlah kasus sifilis primer dan sekunder mencapai 3,2 kasus per 100.000 populasi pada tahun 1997. Faktor risiko yang berhubungan dengan sifilis maternal adalah usia muda, sosial ekonomi rendah, kurangnya pemeriksaan selama kehamilan yang adekuat, pernah menderita penyakit menular seksual, perilaku seksual tinggi, dan pemakai obat narkotika. $2,6,7$ Transmisi transplasental lebih sering terjadi pada ibu hamil yang menderita sifillis primer atau sekunder dibandingkan dengan yang menderita sifilis laten. ${ }^{8}$

\section{Etiologi}

Penyebab sifilis adalah bakteri Treponema pallidum. Treponema berasal dari bahasa Yunani yang berarti benang yang terpuntir. Panjang mikro-organisme ini 5-20 mm dan diameternya 0,092-0,5 mm. ${ }^{1,2,9-11}$

\section{Manifestasi Klinis}

Plasenta dari bayi yang menderita sifilis kongenital dapat mengalami plasentomegali yang didefinisikan oleh Hoddick dkk sebagai penebalan plasenta yang melebihi + 2 SD ( deviasi standar) disesuaikan dengan usia kehamilan. ${ }^{12}$ Kematian janin atau perinatal terjadi pada $40 \%$ bayi yang terinfeksi. ${ }^{8}$ Persalinan preterm dan pertumbuhan janin terhambat juga telah dilaporkan. ${ }^{6}$

Pada bayi yang tetap hidup, manifestasi klinis dibagi dalam stadium dini dan stadium lanjut. Stadium dini terjadi dalam dua tahun pertama kehidupan, sedangkan stadium lanjut terjadi setelah usia dua tahun. Kurang lebih dua pertiga bayi tidak menunjukkan gejala klinis saat dilahirkan, tetapi jika tidak diobati gejala akan muncul dalam beberapa minggu atau bulan. Manifestasi klinis bervariasi dan dapat mengenai beberapa organ. Organ yang sering terkena adalah hati dan limpa berupa pembesaran (hepatosplenomegali), ikterik yang menetap dan peningkatan enzim hati. ${ }^{2,6}$ Limfadenopati bersifat difus dan sembuh dengan sendirinya. Kelainan kulit dapat berupa eritematosa makulopapular atau lesi bula diikuti oleh deskuamasi pada telapak tangan dan kaki. Dapat pula ditemukan lesi kondiloma yang khas pada membran mukosa dan rinitis. Bila terdapat osteokondritis, akan terasa nyeri yang dapat menyebabkan bayi menjadi sensitif dan tidak mau menggerakkan tungkainya (pseudoparalisis Parrot). Kelainan susunan saraf pusat, gagal tumbuh, korioretinits, nefritis, dan sindrom nefrotik dapat juga ditemukan. Manifestasi klinis yang mengenai ginjal dapat berupa hipertensi, hematuria, proteinuria, hipoproteinemia dan hiperkolesterolemia. Hal ini diakibatkan oleh deposit kompleks imun di glomerulus. Gambaran klinis yang jarang dapat berupa gastroenteritis, peritonitis, pankreatitis, pneumonia, kelainan mata (glaukoma dan korioretinitis), hidrops, dan masa pada testis. Manifestasi lanjut merupakan akibat inflamasi kronis pada tulang, gigi, dan susunan saraf pusat.

Perubahan tulang akibat periostitis yang menetap atau berulang dan berhubungan dengan penebalan tulang dapat berupa frontal boosing, penebalan sternoklavikula yang unilateral atau bilateral, bagian tengah tibia yang melengkung ke depan (Saber shins), dan skapula skapoid. Kelainan hidung berupa saddle nose akibat rinitis yang menghancurkan tulang sekitarnya. Manifestasi stadium lanjut dapat berupa keratitis interstitialis yang unilateral atau bilateral dengan gejala fotofobi dan lakrimasi, diikuti opaksifikasi kornea yang mengakibatkan kebutaan pada beberapa minggu sampai dengan beberapa bulan. ${ }^{8}$

\section{Pemeriksaan Penunjang}

Laboratorium darah tepi pada sifilis kongenital 
menunjukkan kelainan berupa anemia, monositosis, dan trombositopenia. ${ }^{2,6,13,14}$ Pemeriksaan serologi dapat dilakukan dengan metode deteksi langsung dengan baku emas pemeriksaan rabbit infectivity test (RIT). Uji serologi non-treponema untuk skrining seperti uji Venereal Disease Research Laboratory (VDRL), Rapid Plasma Reagin (RPR) yang memiliki sensitivitas 70$100 \%$ dan spesifisitas $97-99 \%$, serta uji serologi untuk konfirmasi yaitu Treponema Pallidum Hemagglutination Assay (TPHA), Fluorescent Treponemal Antibody Absorption (FTA-Abs) yang memiliki sensitivitas sebesar 76- $100 \%$ dan spesifisitas $97-99 \% .^{2}$

Pada pemeriksaan histologi jaringan plasenta didapatkan funisitis dan vaskulitis. ${ }^{5}$ Selain itu terdapat juga gambaran plasentitis berupa fibrosis villi korionik dan infiltrat plasmolimfositik pada stroma. ${ }^{15}$

Mikroskop lapangan pandang gelap digunakan untuk mendeteksi adanya bakteri Treponema pallidum dalam cairan tubuh (sekret hidung, serum dari lesi kulit, cairan ketuban). ${ }^{16}$ Pemeriksaan mikroskop lapangan pandang gelap, selain untuk melihat morfologi bakteri, dapat juga melihat pergerakannya yang khas. ${ }^{17}$ Pada pemeriksaan radiologi dapat dijumpai perubahan metafisis tulang panjang. ${ }^{6,18}$

\section{Diagnosis}

Diagnosis sifilis kongenital ditegakkan berdasarkan anamnesis riwayat ibu yang menderita sifilis tanpa pengobatan yang adekuat, atau uji serologis positif, atau pada pemeriksaan mikroskop lapangan pandang gelap ditemukan bakteri Treponema pallidum dalam cairan tubuh. Pada pemeriksaan fisis didapatkan ikterik, hepatosplenomegali, anemia, trombositopenia, kelainan gambaran radiologis tulang panjang, dan kelainan pada cairan serebro spinalis. Pada bayi usia 3-12 minggu dapat ditemukan rinitis, kelainan kulit makulopapular, lesi mukokutan, dan pseudoparalisis. Gambaran khas sifilis kongenital dini adalah saddle nose, gigi Hutchinson, keratitis interstitialis, Saber shins, serta gumma pada hidung dan palatum. ${ }^{3}$

\section{Tata laksana}

Tata laksana sifilis kongenital dibedakan atas empat keadaan yaitu, (Gambar 2)
1. Pada pemeriksaan fisik tampak tanda sifilis kongenital

2 Pada pemeriksaan fisik normal, dibagi menjadi

a. Ibu mempunyai titer $4 \mathrm{X}$, namun tidak diobati.

b. Ibu diobati, titer menurun, dan tidak menderita reinfeksi/relaps.

c. Ibu diobati, titer ibu rendah dan stabil.

\section{Komplikasi}

Komplikasi yang dapat terjadi pada penyakit sifilis adalah neurosifilis. ${ }^{19}$ Neurosifilis terjadi pada kurang lebih $60 \%$ bayi yang menderita sifilis kongenital. $\mathrm{Hal}$ ini ditandai dengan uji VDRL dari bahan CSS (+), pleositosis, dan peningkatan protein. ${ }^{20}$

\section{Prognosis}

Sifilis kongenital yang berat dapat menyebabkan kematian pada masa janin maupun perinatal. Bila penyakit tersebut telah mengenai meningovaskular dapat menyebabkan sekuele permanen. Sifilis Kongenotal dapat sembuh sempurna bila mendapat terapi adekuat. Pengobatan dengan penisilin bersifat kuratif, sehingga perubahan serologi dapat terjadi dalam satu tahun. ${ }^{8}$

\section{Daftar Pustaka}

1. Feigin RD, Cherry JD. Syphilis. Dalam: WB Saunders staff, penyunting. Textbook of Pediatric Infectious Diseases. Edisi ke-2. Philadelphia: WB Saunders Company, 1987. h. 608-20.

2. Sheffield JS, Wendel GD. Syphilis in pregnancy. Clin Obstet Gynecol 1999; 42:97-106.

3. Ogle WJ. Spirochetal infections. Dalam: Hay WW, Groothuis JR, Hayward AR, Levin MJ, penyunting. Current Pediatric Diagnosis and Treatment. Edisi ke-13. Connecticut: Appleton and Lange, 1997. h. 1053-6.

4. Centers for Disease Control. Congenital syphilis. Sexually transmitted diseases treatment guidelines. MMWR 2002; 51:26-8.

5. Mc. Farlin BL, Bottoms SF, Dock BS, Isada NB. Epidemic syphilis: Maternal factors associated with congenital infection. Am J Obstet Gynecol 1994; 170:535-40.

6. Humphrey MD, Bradford DL. Congenital syphilis: still a reality in 1996. Med J Am 1996; 165:382-5. 


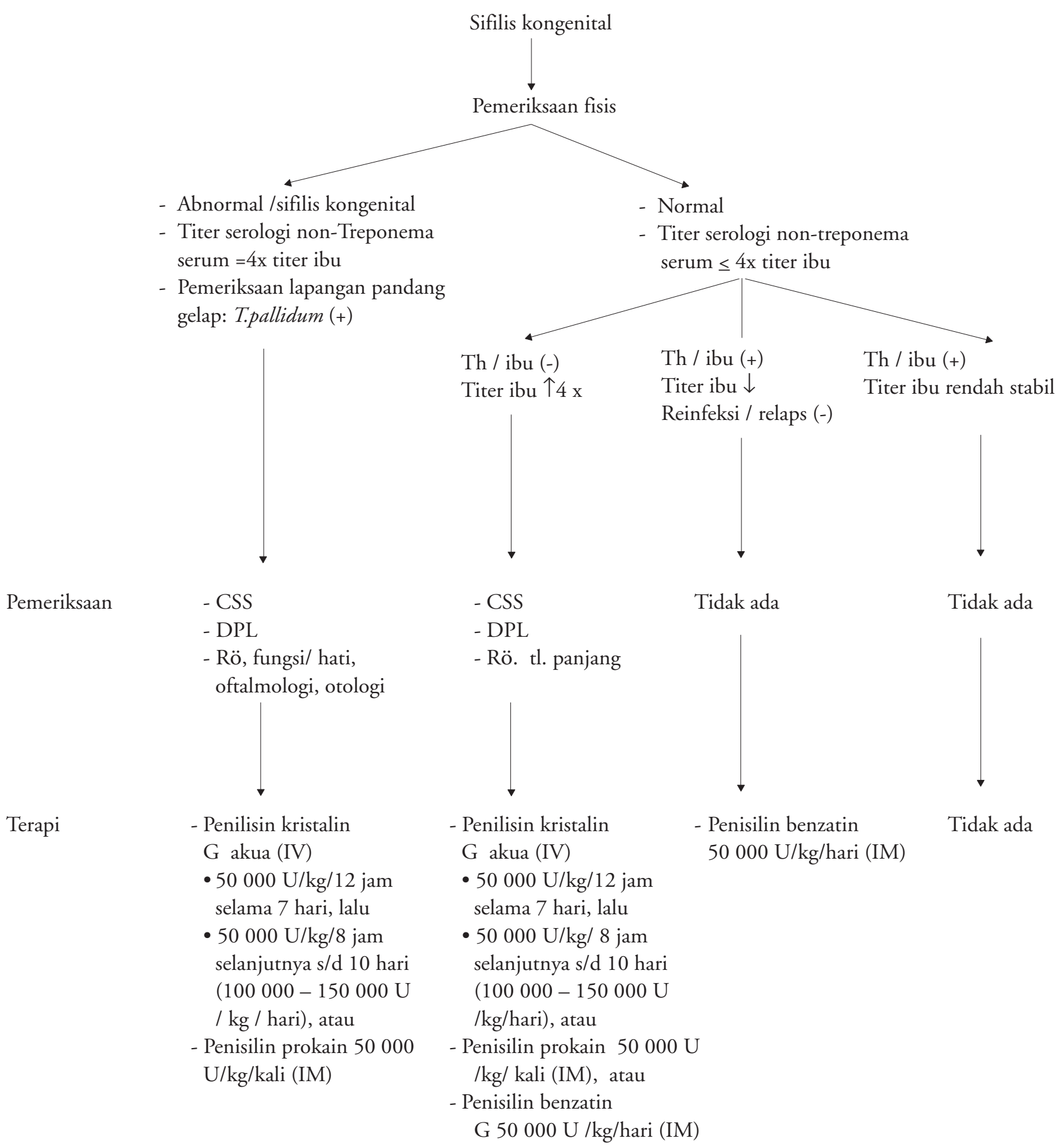

Gambar 2. Tata laksana sifilis kongenital ${ }^{4}$ 
7. Leach CR, Bothe JA. Syphilis in Kentucky 1993-1996. Kentucky epidemiologic notes and reports 1997; 1-6.

8. Azimi P. Syphilis (Treponema pallidum). Dalam: Behrman RE, Kliegman RM, Jensen BH, penyunting. Nelson Textbook of Pediatrics. Edisi ke-16. Philadelphia: WB Saunders Company, 2000 . h. 903-14.

9. Kolman CJ, Lara AC, Lukehart SA, Owsley W, Tuross N. Idetification of Treponema palllidum subspecies pallidum in a 200-year-old skeletal specimen. J Infect Dis 1999; 180:2060-3.

10. Egglestone SI, Turner AJL. Serological diagnosis of syphilis. Commun Dis Public Health 2000; 3:158-62.

11. Terkait NM, Aboobacker KC. Congenital syphilis: Case report and review of the literature. Kuwait Med J 2002; 34:43-6.

12. Hollier ML, Harstad TW, Sanchez PJ, Twickler DM, Wendel GD. Fetal syphilis: Clinical and laboratory characteristics. Obstet Gynecol 2001; 97:947-53.

13. Dorfman DH, Glaser JH. Congenital syphilis presenting in infant after the newborn period. N Engl J Med 1990; 323:1299-302.

14. Sheffield JS, Sanchez PJ, Morris G, Maberry M, Zeray F, Mc Intire DD, dkk. Congenital syphilis after mater- nal treatment for syphilis during pregnancy. Am J Obstet Gynecol 2002; 186:569-73.

15. Ricci JM, Fojaco RM, O’Sullivan MJ. Congenital syphilis: The University of Miami/Jackson Memorial Medical Center Experience, 1986-1988. Obstet Gynecol 1989; 74:687-93.

16. Wendel GD, Sanchez PJ, Peters MT, Harstad TW, Potter LL, Norgard MV. Identification of Treponema pallidum in amniotic fluid and fetal blood from pregnancies complicated by congenital syphilis. Obstet Gynecol 1991; 78:890-5.

17. Wendel GD, Maberry MC, Christmas JT, Goldberg MS, Nogard MV. Examination of amniotic fluid in diagnosing congenital syphilis with fetal death. Obstet Gynecol 1989; 74:967-70.

18. Mascola L, Pelosi R, Alexander CE. Inadequate treatment of syphilis in pregnancy. Am J Obstet Gynecol 1984; 150:945-7.

19. Rolfs RT, Joesoef MR, Hendershot EF, RompaloAM, Augenbraun MH, Chiu M, dkk. A randomized trial of enhanced therapy for early syphilis in patients with and without human immunodeficiency virus infection. $\mathrm{N}$ Engl J Med 1997; 337:307-14. 